\title{
Isoflavon Kedelai Diperkaya dengan Zn sebagai Suplemen Antiarterosklerosis Wanita Premenopause
}

Soy Isoflavone Enriched by Zn as an Antiatheroschlerosis Supplement in Premenopausal Women

\section{Hery Winarsi}

Fak. Biologi UNSOED Purwokerto Jl. Suparno Karangwangkal Purwokerto 53122

Telp: (0281)638794, Fax: (0281)631700,E-mail: winarsi@yahoo.com

\begin{abstract}
This research was conducted to observe the effect of soy isoflavone and $\mathrm{Zn}$ on total cholesterol, LDL, TG and HDL levels of premenopausal women. Thirty-three premenopausal women in Purwokerto were given supplement containing soy isoflavone and $\mathrm{Zn}$ during 2 months. In the control group (SO), 11 women were given placebo; in the group SI, 11 women were given the supplement containing soy isoflavone; and in the group SIZ, 11 women were given the supplement containing soy isoflavone and $\mathrm{Zn}$. Blood samples were taken 3 times, i.e. baseline, 1 and 2 month after intervention. One ml of blood was taken by venoject-heparin, intravenously. Blood plasma was used to determine total cholesterol, LDL, HDL, and TG levels using spectrophotometer. Data obtained were analysed by ANOVA. The total cholesterol, LDL, and TG plasma levels decreased, from 189,27 to $151,63 \mathrm{mg} / \mathrm{dl}(\mathrm{p}=0,02)$; from 138,97 to $93,93 \mathrm{mg} / \mathrm{dl}(\mathrm{p}=0,004)$; and from 208,81 to $121,09 \mathrm{mg} / \mathrm{dl}(\mathrm{p}=0,012)$ respectively. On the contrary HDL level increased, from 48,38 to $67,27 \mathrm{mg} / \mathrm{dl}(\mathrm{p}=1,72 \mathrm{E}-05)$ after 2 months of intervention. Soy isoflavone and $\mathrm{Zn}$ (SIZ) have potential as antiatherosclerosis supplement.
\end{abstract}

Key words: Cholesterol total, LDL, TG, HDL, soy isoflavone \& Zn, premenopausal women

Diterima: 03 Januari 2007, disetujui: 18 Mei 2007

\section{Pendahuluan}

Arterosklerosis adalah kondisi patologis yang disebabkan oleh adanya pengerasan pembuluh darah arteri, hilangnya elastisitas, dan penyempitan lumen. Kondisi seperti ini merupakan faktor risiko timbulnya penyakit jantung koroner. Menurut Priyana (2004) arterosklerosis diawali dengan kerusakan endotel dan tingginya kadar kolesterol LDL (Low Density Lipoproten). Kolesterol LDL merupakan jenis kolesterol "jahat", yang menumpuk di lapisan dalam (tunika intima) dan teroksidasi (LDLox). Kerusakan endotel juga memungkinkan LDL melakukan penetrasi ke bagian dalam pembuluh darah arteri, sehingga terjadi penumpukan lipoprotein.
Penumpukan terutama LDLox memacu sel monosit melakukan fagosit. Seiring dengan meningkatnya aktivitas makrofag melalui reseptor scavenger, makin banyak pula terbentuknya LDLox, sehingga terjadi peningkatan kandungan kolesterol pada makrofag yang membentuk sel busa pada fatty streak (Shih et al., 1995; Steinberg, 1997).

Bila kadar kolesterol HDL (High Density Lipoprotein) tinggi, maka kolesterol LDL akan ditarik keluar oleh HDL (High Density Lipoprotein) dari sel busa makrofag, sehingga terbentuknya arterosklerosis dapat dihambat (Mackness et al., 1993). Disamping itu, sel-sel otot polos pada tunika media berproliferasi dan memproduksi sejenis protein (matriks) yang melapisi arterosklerosis sehingga mempertebal 
lapisan dalam pembuluh koroner. Sumbatan arterosklerosis bersifat rentan untuk pecah. Bila sumbatan pecah, akan terjadi reaksi pembekuan darah (trombosis) dan menambah tebal sumbatan, reaksi trombosis dapat mengakibatkan peningkatan derajat sumbatan. Pada sumbatan parsial akan terjadi angina pektoris yang tidak stabil, pada sumbatan total, sel otot jantung dapat mati.

Kondisi defisiensi estrogen ovarium pada wanita premenopause dapat memicu penyakit degeneratif. Rendahnya status antioksidan pada wanita premenopause di Purwokerto (Winarsi et al., 2005) mempermudah seorang wanita terkena penyakit arterosklerosis.

Di sisi lain banyak peneliti yang melaporkan bahwa isoflavon kedelai bersifat antioksidatif, estrogenik, antikarsinogenik, dan antiosteoporositik (Cassidy et al., 1994; Barnes, 1995; Winarsi et al., 2004). Oleh karena itu, isoflavon mampu menangkap radikal bebas dan mengubahnya menjadi senyawa yang relatif stabil sehingga mencegah kerusakan komponen biologis.

Selain oleh peran antioksidan isoflavon, integritas sel juga dapat dipertahankan oleh status Zn tubuh (Cakman et al., 1996; Wresdiyati et al., 2004). Winarsi et al., (2005) menyatakan bahwa defisiensi $\mathrm{Zn}$ sering menyertai kehidupan wanita usia lanjut, seperti pada wanita premenopause.

Penelitian ini bertujuan untuk mengetahui pengaruh pemberian isoflavon kedelai dan Zn terhadap kadar kolesterol total, LDL, HDL dan trigliserida plasma wanita premenopause.

\section{Metode Penelitian}

Dalam penelitian ini melibatkan 33 wanita premenopause, berumur 43-52 tahun, dan bertempat tinggal di wilayah kota Purwokerto. Intervensi dilakukan selama 2 bulan. Responden dibagi dalam 3 kelompok, setiap kelompok terdiri atas 11 responden. Kelompok kontrol (SO) diintervensi dengan plasebo (tanpa isoflavon kedelai \& Zn), kelompok SI diintervensi dengan minuman yang mengandung isoflavon kedelai, dan kelompok SIZ diintervensi dengan minuman yang mengandung isoflavon kedelai \& $\mathrm{Zn}$ Pengambilan sampel darah dilakukan 3 kali, yaitu saat baseline, serta 1 bulan dan 2 bulan setelah intervensi, intravena. Penentuan kadar kolesterol total secara enzimatis menggunakan metode CHOD-PAP (Richmond, 1973), kadar HDL ditentukan secara enzimatis dengan metode CHOD-PAP (Lopes-Virella et al. 1977). Trigliserida ditentukan secara enzimatis dengan metode GOP-PAP (McGowan et al., 1983). Bila kadar trigliserida $<400 \mathrm{mg} / \mathrm{dl}$, maka LDL ditentukan dengan rumus Friedwald, yaitu: LDL $=\mathrm{K}-\mathrm{HDL}-(\mathrm{TG} / 5)$. Data dianalisis dengan sidik ragam, dan bila ada pengambilan yang nyata dilanjutkan uji Duncan.

\section{Hasil dan Pembahasan}

\section{Kolesterol Total}

Hasil analisis sidik ragam antarkelompok tidak menunjukkan perbedaan kadar kolesterol total pada baseline dan 1 bulan setelah intervensi, akan tetapi setelah 2 bulan intervensi, terjadi penurunan secara nyata pada kelompok SIZ (Gambar 1), yaitu dari 189,27 $\mathrm{mg} / \mathrm{dl}$ menjadi $151,63 \mathrm{mg} / \mathrm{dl} \quad(\mathrm{p}=0,02)$. Kelompok SIZ berbeda dengan kelompok SI, sedangkan kelompok SI tidak berbeda dengan kelompok kontrol. Menurunnya kolesterol total bukan karena suplementasi isoflavon tunggal melainkan karena interaksi isoflavon dan $\mathrm{Zn}$. Hasil ini mendukung temuan Anderson \& Wolf (1995) yang memberikan $47 \mathrm{~g} /$ hari protein kedelai pada 38 orang, ternyata protein kedelai dapat menurunkan kolesterol serum sebesar 9\%. Teixeira (1998) juga menyatakan bahwa protein kedelai yang mengandung isoflavon, secara nyata menurunkan kadar kolesterol total pada pria hiperkolesterolemi sedang.

Isoflavon kedelai menunjukkan potensinya ketika senyawa tersebut terikat dengan protein. Potter (1996) menyatakan bahwa peran protein kedelai dalam menurunkan kadar kolesterol darah, melalui peningkatan ekskresi asam empedu pada tikus percobaan. Hal yang sama juga terjadi pada manusia, melalui ekskresi steroid netral dalam feses dan asam empedu, sehingga kadar kolesterol darah menurun (Fumagalli et al.,

Biota Vol. 12 (2), Juni 2007 
1982). Diduga isoflavon kedelai mirip dengan flavonoid teh yang mampu menghambat $\beta$ hidroksi- $\beta$-metilglutaril koenzim A (HMGCoA) (Chan et al., 1999). HMG-CoA merupakan enzim utama dalam sintesis kolesterol dan asil-CoA intestinal. Enzim tersebut berperan dalam esterifikasi kolesterol, sebelum kolesterol diserap dan diubah menjadi kilomikron dalam usus. Selain itu, isoflavon juga menurunkan kelarutan misel, absorpsi kolesterol dan asam empedu dalam usus. Penurunan kadar kolesterol, berkaitan dengan lambatnya absorpsi asam amino non esensial dalam tepung isoflavon kedelai (Song et al.,
1998), sehingga ketersediaaan asetil CoA untuk sintesis kolesterol juga rendah.

Anderson \& Wolf (1995) berpendapat bahwa kandungan serat dan fitat dalam tepung isoflavon kedelai dapat mengganggu metabolisme kolesterol, sehingga menyebabkan kadar kolesterol darah menurun. Mineral Zn berperan sebagai antioksidan, yaitu dengan cara menginduksi aktivitas enzim SOD (Winarsi et al., 2005; Wresdiyati et al., 2004), sehingga reaktivitas radikal bebas dapat dihambat. Diduga pemberian $100 \mathrm{mg}$ isoflavon kedelai dan $8 \mathrm{mg}$ mineral $\mathrm{Zn}$ kepada wanita premenopause, bekerja secara sinergis menekan kadar kolesterol darah.

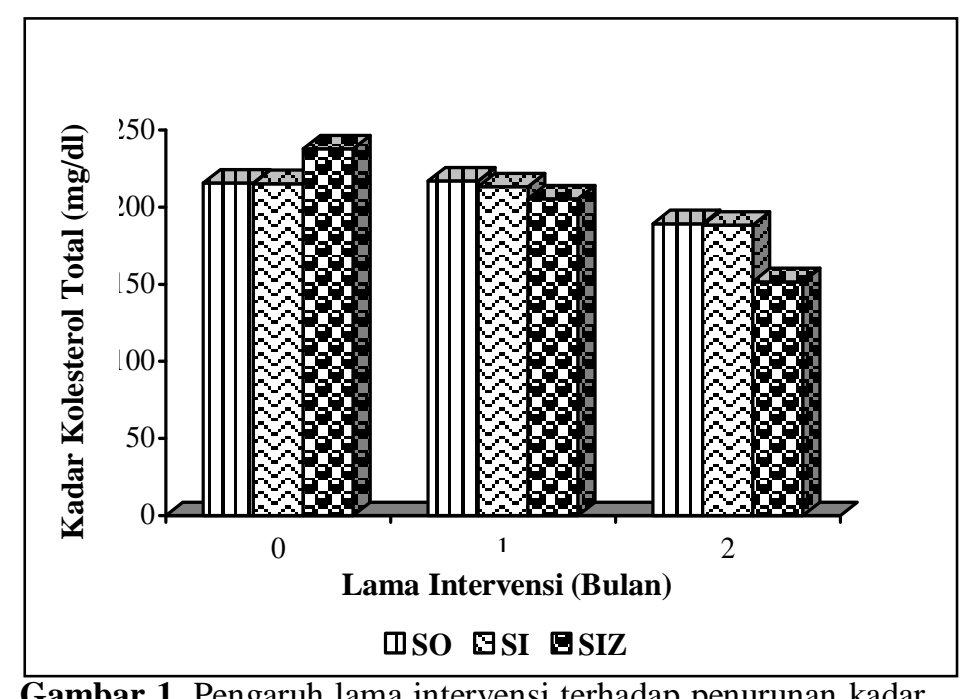

Gambar 1. Pengaruh lama intervensi terhadap penurunan kadar kolesterol total wanita premenopause

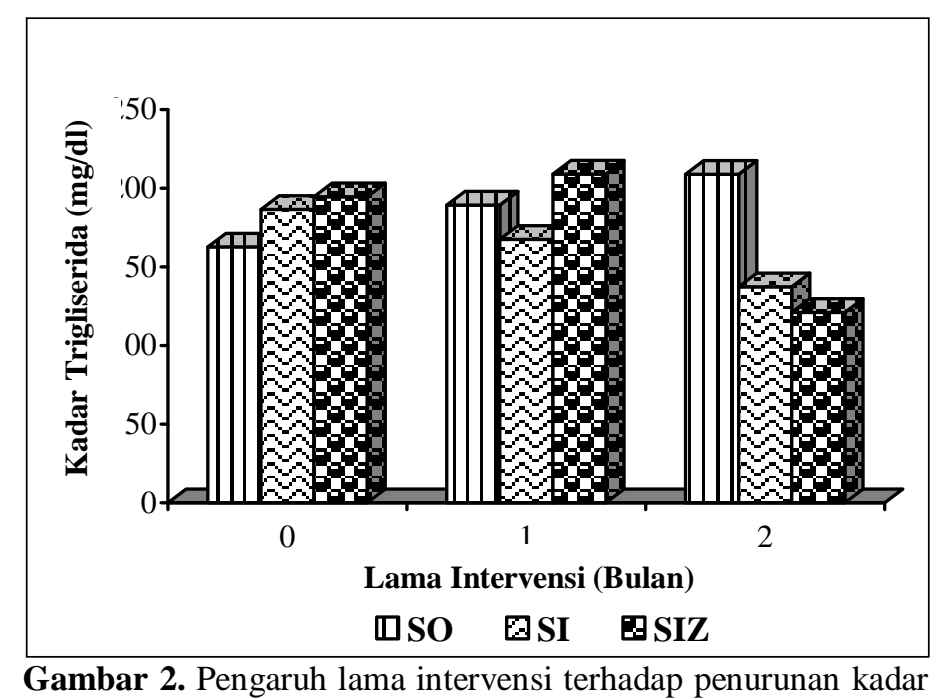

trigliserid darah wanita premenopause 


\section{Trigliserida darah}

Pada saat baseline dan 1 bulan setelah intervensi, hasil analisis sidik ragam antarkelompok tidak menunjukkan adanya perbedaan kadar trigliserida darah. Setelah 2 bulan intervensi, terjadi penurunan secara nyata pada kelompok SIZ (Gambar 2), yaitu dari $208,81 \mathrm{mg} / \mathrm{dl}$ menjadi $121,09 \mathrm{mg} / \mathrm{dl}(\mathrm{p}=$ 0,012). Dalam penelitian ini kelompok SIZ tidak berbeda dengan kelompok SI. Penurunan trigliserida dapat disebabkan oleh isoflavon tunggal, maupun interaksinya dengan mineral Zn.

Peran isoflavon dalam menurunkan resiko arterosklerosis, diketahui melalui perbaikan kadar lipid dan lipoprotein plasma. Menurut Viana et al., (1996) isoflavon kedelai mampu menekan pembentukan agregasi platelet, menghambat proliferasi dan adesi sel dalam arteri. Sementara itu Kim et al., (1998) menyatakan bahwa isoflavon melindungi dinding pembuluh darah arteri coronaria supaya tidak mudah dilekati ateroma, dengan cara (a) menghambat proliferasi sel-sel otot polos, (b) meningkatkan fungsi sel endotel, dan (c) mencegah terjadinya inflamasi. Anthony (2000) menyatakan bahwa isoflavon kedelai sangat bermanfaat bagi fungsi vaskuler dan sel endotel, aktivasi dan agregasi platelet, LDLox, proliferasi dan migrasi sel otot polos, namun mekanisme kerjanya belum diketahui dengan pasti.

\section{Kolesterol HDL}

Hasil analisis sidik ragam antar kelompok menunjukkan peningkatan kadar kolesterol HDL secara nyata. Setelah 2 bulan intervensi pada kelompok SIZ (Gambar 3), yaitu dari 48,38 menjadi $67,27 \mathrm{mg} / \mathrm{dl}(\mathrm{p}=$ 1,72E-05). Kelompok SIZ berbeda dengan kelompok SI. Hal ini menunjukkan bahwa peningkatan kolesterol HDL bukan karena suplementasi isoflavon tunggal, tetapi karena interaksi isoflavon dan $\mathrm{Zn}$. Temuan ini agak berseberangan dengan pendapat Teixeira (1998) yang menyatakan bahwa isoflavon protein kedelai, mempertahankan kadar HDL pada pria hiperkolesterolemi sedang. Mackness et al., (1993) berpendapat bahwa tingginya HDL dapat menghambat pembentukan peroksida lipid dalam LDL hingga 90\%. Sementara itu, Zn merupakan komponen antioksidan berperan melindungi sel-sel tubuh dari serangan radikal bebas. Oleh sebab itu pengkayaan $\mathrm{Zn}$ ke dalam isoflavon kedelai dapat memperbaiki struktur sel sehingga dapat berfungsi secara normal (Rink \& Kirchner, 2000). Hal ini sesuai dengan pernyataan Meydani (2000) bahwa dengan mengkonsumsi antioksidan dalam jumlah tertentu dapat menurunkan risiko penyakit kardiovaskuler, yaitu dengan meningkatkan kolesterol HDL.

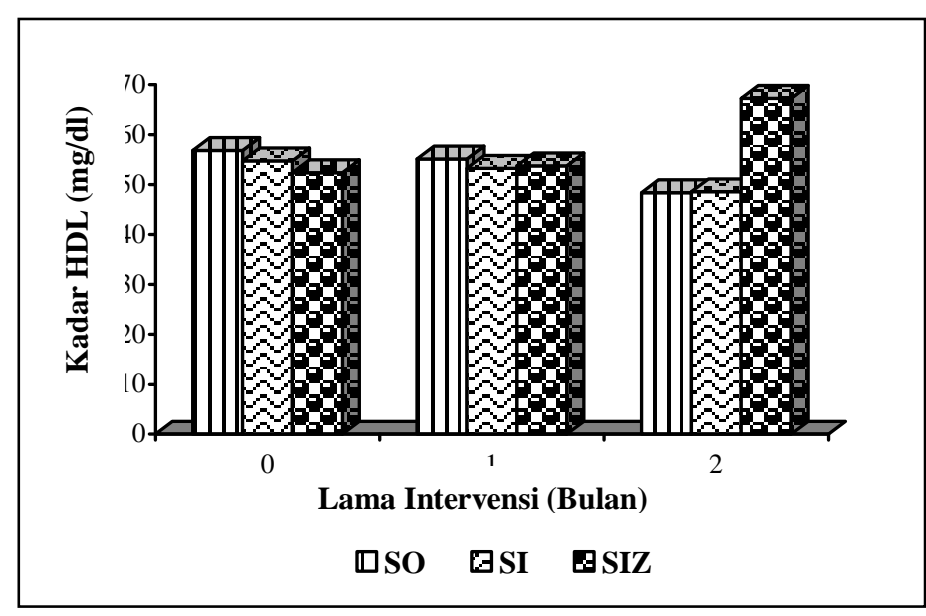

Gambar 3. Pengaruh lama intervensi terhadap peningkatan kadar HDL wanita premenopause 
Mackness et al., (1993) berpendapat bahwa HDL merupakan antioksidan yang sangat kuat dan inhibitor LDL-ox, yang berperan penting dalam mencegah arterosklerosis. HDL adalah lipoprotein pengangkut kolesterol dari ekstra hepatik ke hepar. Peningkatan HDL sangat berkaitan dengan menurunnya trigliserida. Salah satu fungsi $\mathrm{HDL}$ adalah mensintesis reseptor LDL (Adiwijono \& Asdic, 1993). Peningkatan HDL mengakibatkan sintesis reseptor LDL meningkat pula. Semua bentuk kolesterol yang akan dibuang harus melewati hepar, kemudian disekresi dalam empedu baik sebagai kolesterol maupun asam kolat dalam garam empedu.

Isoflavon kedelai mengatur homeostasis sterol selular. Menurut Mullen et al., (2004) isoflavon berperan dalam maturasi protein yang mengekspresikan gen pengatur sterol sebagai pengendali metabolisme lipid. Mekanisme isoflavon dalam menurunkan kolesterol belum diketahui secara pasti. Anthony et al., (1997) menyatakan bahwa asam amino arginin dan glisin yang banyak terkandung dalam tepung isoflavon kedelai mampu menurunkan kolesterol. Tidak seperti halnya protein hewani yang miskin asam-asam amino tersebut, tetapi kaya lisin justru meningkatkan sintesis kolesterol dalam hepar.

Struktur isoflavon kedelai mirip estrogen. Oleh sebab itu isoflavon secara agonis dapat binding dengan reseptor estrogen, dan merestorasi hormon tersebut secara cepat pada wanita postmenopause (Herrington et al., 1994). Estrogen berperan memperbaiki metabolisme lipid (Sirtori et al., 1984) sehingga berkembangnya arterosklerosis dapat dicegah.

Para peneliti meyakini bahwa isoflavon bersifat antioksidan. Kanazawa et al., (1993) melaporkan isoflavon kedelai mengurangi kadar LDL, dan melindungi dari oksidasi. Secara in vivo isoflavon mampu mencegah oksidasi LDL sehingga tidak terbentuk ateroma pada dinding arteri. Isoflavon menghambat migrasi dan proliferasi sel otot polos (Shimokado et al., 1995), yang berperan dalam promosi dan progresi arterosklerosis. Isoflavon juga menekan pembentukan trombus dengan cara mencegah terjadinya aktivasi platelet (Kuruvilla et al., 1993), agregasi platelet
(McNicol, 1993) dan ambilan serotonin platelet (Helmeste \& Tang, 1995). Wilcox \& Blumenthal (1995) menyatakan bahwa isoflavon berpengaruh pada reaktivitas vaskuler (Gould et al., 1995), yang berefek negatif pada arterosklerosis. Anthony et al., (1998) meneliti reaktivitas vaskuler pada monyet yang diberi pakan rendah isoflavon, diameter lumennya konstriksi $6 \%$. Sebaliknya monyet yang diberi pakan tinggi isoflavon diameter lumennya mengalami dilatasi. Honore et al., (1997) menuturkan bahwa penggunaan isoflavon secara injeksi, mampu merestorasi vasodilatasi dalam hewan percobaan yang sebelumnya mengalami konstriksi.

\section{Kolesterol LDL}

Hasil analisis sidik ragam antar kelompok tidak menunjukkan perbedaan kadar kolesterol LDL pada baseline dan 1 bulan setelah intervensi, akan tetapi setelah 2 bulan intervensi terjadi penurunan secara nyata pada kelompok SIZ (Gambar 4), yaitu dari 138,97 menjadi $93,93 \mathrm{mg} / \mathrm{dl} \quad(\mathrm{p}=0,004)$. Kelompok SIZ tidak berbeda dengan kelompok SI, oleh sebab itu penurunan LDL dapat karena suplementasi isoflavon tunggal, maupun interaksinya dengan $\mathrm{Zn}$.

LDL adalah lipoprotein dalam darah yang berfungsi untuk mengangkut kolesterol dari hepar ke jaringan. Selain itu diduga menurunnya LDL berkaitan dengan meningkatnya aktivitas reseptor LDL hepar (Potter, 1995). Penurunan LDL juga seiring dengan penurunan trigliserida.

Status $\mathrm{Zn}$ yang memadai mampu mengurangi plak arterosklerosis pada penderita penyakit jantung iskemik dan infark miokardial akut (Vlad et al., 1994). Mekanisme fungsi proteksi $\mathrm{Zn}$ dalam arterosklerosis, termasuk dalam hal disfungsinya respon sel vaskuler dan inflamasi, belum diketahui secara pasti. Menurut Reiterer et al., (2005) dan Wresdiyati et al., (2004) bahwa $\mathrm{Zn}$ bersifat antioksidan dan antiinflamasi. Menurut Klotz et al., (2003) $\mathrm{Zn}$ sebagai komponen protein struktural mampu menstabilkan gugus thiol, dan menjaga protein tidak mudah teroksidasi. De Nigris et al., (2001) mengemukakan bahwa tekanan oksidatif dapat menyebabkan NF- $\mathrm{KB}$, faktor transkripsi proinflamasi memperantarai 
teraktivasinya sel endotel. Sifat antioksidan Zn juga penting untuk melindungi PPAR (Peroxisome Proliferator Activated Receptors) $\alpha$ dan $\beta$ dalam sel endotel. PPAR diketahui sebagai reseptor yang berperan dalam berbagai jalur metabolik, termasuk metabolisme lipid
(Reiterer et al., 2004; Torra et al., 2001). Sifat anti inflamasi $\mathrm{Zn}$ dapat melindungi serangan aktivasi sel endotel. Bukti klinis menunjukkan bahwa aktivasi PPAR mampu menekan kejadian penyakit kardiovaskuler (Torra et al., 2001).

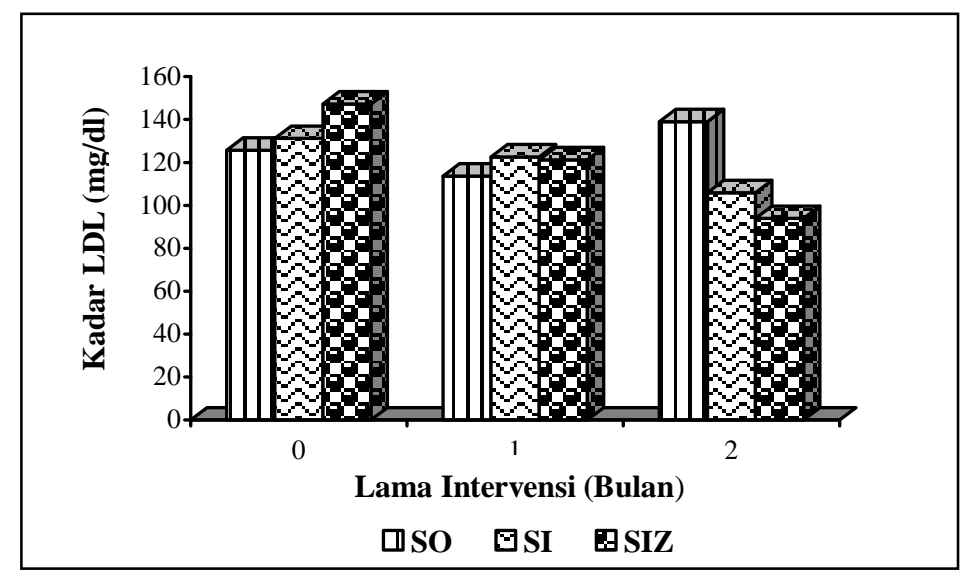

Gambar 4. Pengaruh lama intervensi terhadap penurunan kadar LDL wanita premenopause

\section{Kesimpulan}

Berdasarkan penelitian ini dapat disimpulkan bahwa pemberian suplementasi isoflavon kedelai yang diperkaya dengan $\mathrm{Zn}$ dapat menurunkan kadar kolesterol total, LDL, dan trigliserida, serta meningkatkan kolesterol HDL pada wanita premenopause. Hasil penelitian ini membuktikan bahwa isoflavon kedelai yang diperkaya Zn berpotensi sebagai antiarterosklerosis.

\section{Daftar Pustaka}

Adiwijono and Asdic, A.H. 1993. Dislipidemia pada diabetes melitus tipe II. Patofisologi dan pendekatan terapi. Berkala Ilmu Kedokteran XXV (4): 189-201.

Anderson, R.L. and Wolf, W.J. 1995. Compositional changes in trypsin inhibitors, phytic acid, saponins and isoflavones related to soybean processing. J. Nutr 125: 581S-588S.

Anthony, M.S. 2000. Soy and cardiovascular disease: cholesterol lowering and beyond. J. Nutr 130: 662S-663S
Anthony, M.S., Clarkson, T.B., Bullock, B.C. and Wagner, J.D. 1997. Soy protein versus soy phytoestrogens in the prevention of dietinduced coronary artery atherosclerosis of male cynomolgus monkeys. Arterioscler Thromb Vasc Biol 17: 2524-31.

Anthony, M.S., Clarkson, T.B. and Williams, J.K. 1998 Effects of soy isoflavones on atherosclerosis: potential mechanisms. Am J. Clin Nutr. 68(suppl): 1390S-3S.

Barnes, S. 1995. Effect of genistein on in vitro and in vivo models of cancer. J. Nutr 125: 777S$783 \mathrm{~S}$

Cakman, I., Rohwer, J., Schutz, R.M., Kirchner, H. and Rink, L. 1996. Dysregulation between TH-1 and TH-2 T-cell subpopulations in the elderly. Mechan Ageing Dev 87: 197-209.

Cassidy, A., Bingham, S. and Setchell, K.D. 1994 Biological effects of a diet of soy protein rich in isoflavones on the menstrual cycle of premenopausal women. Am J. Clin Nutr 60: $333-340$

Chan, P.T., Fong, W.P., Cheung, Y.L., Huang, Y., Ho, W.K.K. and Chen, Z-Y. 1999. Jasmine green tea epicatechins are hypolipidemic in hamsters (Mesocricetus auratus) fed a high fat diet. J. Nutr 129: 1094-1101 
De Nigris, F., Lerman, L.O., Condorelli, M., Lerman, A. and Napoli, C. 2001. Oxidation-sensitive transcription factors and molecular mechanisms in the arterial wall. Antioxid. Redox Signal 3: 1119-1130.

Fumagalli, R., Soleri, L, Farina, R., Musanti, R., Mantero, O., Noseda, G., Gatti, E. and Mantero, O., Noseda, G., Gatti, E. and
Sirtori, C.R. 1982. Fecal cholesterol excretion studies in type II hypercholesterolemic patients treated with soybean protein diet. Atherosclerosis 43: 341-353.

Gould, E.M., Rembold, C.M. and Murphy, R.A. 1995. Genistein, a tyrosine kinase inhibitor, reduces $\mathrm{Ca}^{2+}$ mobilization in swine carotid media. $\mathrm{Am}$ J. Physiol 268: C1425-9.

Helmeste, D.M. and Tang, S.W. 1995. Tyrosine kinase inhibitors regulate serotonin uptake in platelets. Eur J. Pharmacol 280: R5-7.

Herrington, D.M., Braden, G.A., Williams, J.K. and Morgan, T.M. 1994. Estrogen modulates coronary vasomotor responses in postmenopausal women with early postmenopausal women with early
atherosclerosis. Am J. Cardiol 73: 951-952.

Honore, E.K., Williams, J.K., Anthony, M.S. and Clarkson, T.B. 1997. Soy isoflavones enhance coronary vascular reactivity in atherosclerotic female macaques. Fertil Steril 67: 148-154.

Kanazawa, T., Tanaka, M. and Uemura, T. 1993. Antiatherogenicity of soybean protein. Ann $N Y$ Acad Sci 676: 202-214.

Kim, H.P., Mani, I., Iversen, L. and Ziboh, V.A. 1998. Effects of naturally occurring flavonoids and bioflavonoids on epidermal cyclooxygenase and lypoxygenase from guinea pigs. Prostaglandins Leukot Essent Fatty Acids 58: 17-24.

Klotz, L.O., Kroncke, K.D., Buchczyk, D.P. and Sies, H. 2003. Role of copper, zinc, selenium and tellurium in the cellular defense against oxidative and nitrosative stress. J. Nutr 133: 1448S-1451S.

Kuruvilla, A., Putcha, G., Poulos, E. and Shearer, W.T. 1993. Tyrosine phosphorylation of phospholipase $\mathrm{C}$ concomitant with its activation by platelet-activating factor in a activation by platelet-activating factor in a
human B cell line. J. Immunol 151: 637-648.

Lopes-Virella, M.F., Stone, P., Ellis, S. and Colwell, J.A. 1977. Cholesterol determination in High Density Lipoprotein separated by three different methods. Clin Chem 23: 882-884.
Mackness, M.I., Abbott, C., Arrol, S. and Durrington, P.N. 1993. The role of high density lipoprotein and lipid soluble antioxidant vitamins in inhibiting low density lipoprotein oxidation. Biochem J. London 294 (3): 829 834.

McGowan, M.W., Artiss, J.D., Strandbergh, D.R., Zak, B 1983. A peroxidase-coupled methods for the colorimetric determination of serum triglyserides. Clin Chem 29: 538-542.

McNicol, A. 1993. The effects of genistein on platelet function are due to thromboxane receptor antagonism rather than inhibition of tyrosine kinase. Prostaglandins Leukot Essent Fatty Acids 48: 379-384.

Meydani, M. 2000. Effect of functional food ingredients: Vitamin E modulation of cardiovascular diseases and immune status in the elderly. Am J. Clin Nutr 71 (6 Suppl): 1665S.

Mullen, E., Brown, R.M., Osborne, T.F. and Shay, N.F. 2004. Soy isoflavones affect Sterol Regulatory Element Binding Proteins (SREBPs) and SREBP-Regulated genes in HepG2 Cells. J. Nutr 134 (11): 2942-2947.

Potter, S.M. 1995. Overview of proposed mechanisms for the hypocholesterolemic effect of soy. J. Nutr 125: 606S-611S.

Potter, S.M. 1996. Soy protein and serum lipids. Curr Opin Lipidol 7: 260-264.

Priyana, A. 2004. Anggur Merah Baik untuk Jantung? http://www.kompas.com/kompascetak/0404/14/ilpeng/969485.htm. 16/6/2004.

Reiterer, G., Toborek, M. and Hennig, B. 2004. Peroxisome proliferator activated receptors $\alpha$ and $\gamma$ require zinc for their anti-inflammatory properties in porcine vascular endothelial cells. J. Nutr 134: 1711-1715.

Reiterer, G., MacDonald, R., Browning, J.D., Morrow, J., Matveev, S.V., Daugherty, A., Smart, E., Toborek, M. and Hennig, B. 2005. Zinc Deficiency Increases Plasma Lipids and Atherosclerotic Markers in LDL-ReceptorDeficient Mice. J. Nutr 135: 2114-2118.

Richmond, W. 1973. Enzymatic determination of total serum cholesterol. Clin Chem 19: 1350-1354.

Rink, L. and Kirchner, H. 2000. Zinc-altered immune function and cytokine production. J. Nutr 130: 1407S-1411S.

Shih, D.M., Welch, C. and Lusis, A.J. 1995. New Insights into atherosclerosis from Studies with Mouse Models. Molecular Medicine Today 1: 364372. 
Shimokado, K., Umezawa, K. and Ogata, J. 1995. Tyrosine kinase inhibitors inhibit multiple steps of the cell cycle of vascular smooth muscle cells. Exp Cell Res 220: 266-273.

Sirtori, C.R., Galli, G., Lovati, M.R., Carrara, P., Bosisio, E. and Kienle, M.G. 1984. Effect of dietary proteins on the regulation of liver lipoprotein receptors in rats. J. Nutr 114: 1493-500.

Song, T., Barua, K., Buseman, G. and Murphy, P.A. 1998. Soy isoflavone analysis: quality control and a new internal standard. Am J. Clin Nutr 68: 1474S-1479S.

Steinberg, D. 1997. Oxidative modification of low density lipoprotein and atherosclerosis. Circulation 95: 1062-1071.

Teixeira, S. 1998. Dose dependent effects of soy protein in hypercholesterolemic men. FASEB J. 12: A237.

Torra, I.P., Chinetti, G., Duval, C., Fruchart, J.C. and Staels, B. 2001. Peroxisome proliferatoractivated receptors: from transcriptional control to clinical practice. Curr. Opin. Lipidol 12: 245-254.

Vlad, M., Caseanu, E., Uza, G. and Petrescu, M. 1994. Concentration of copper, zinc, chromium, iron and nickel in the abdominal aorta of patients deceased with coronary heart disease. J. Trace Elem. Electrolytes Health Dis 8: 111-114.
Wilcox, J.N. and Blumenthal, B.F. 1995. Thrombotic mechanisms in atherosclerosis: potential impact of soy proteins. J. Nutr 125 (suppl): 631S-638S.

Winarsi, H., Muchtadi, D., Zakaria, F.R. dan Purwantara, B. 2004. Respons hormonal-imunitas wanita premenopause yang diintervensi minuman fungsional berbasis susu skim yang disuplementasi dengan isoflavon kedelai dan Zn-sulfat. J. Teknol \& Industri Pangan 15 (1): 28-34.

Winarsi, H., Muchtadi, D., Zakaria, F.R. dan Purwanto, A. 2005. Kajian tentang wanita perimenopause di purwokerto dan beberapa permasalahan dalam sistem imunnya. $J$. permasalahan dalam sistem imunnya. J.
Obstetri \& Ginekologi Indonesia 29(3): 177183.

Wresdiyati, T., Adnyane, I.K.M., Prabandari, S.A., dan Sofiawati. 2004. Profil Imunohistokimia Antioksidan Copper, Zinc-Superoxide Dismutase (Cu, Zn-SOD) pada Ginjal Tikus Perinatal dan Neonatal. Biota 9 (3): 163-170. 